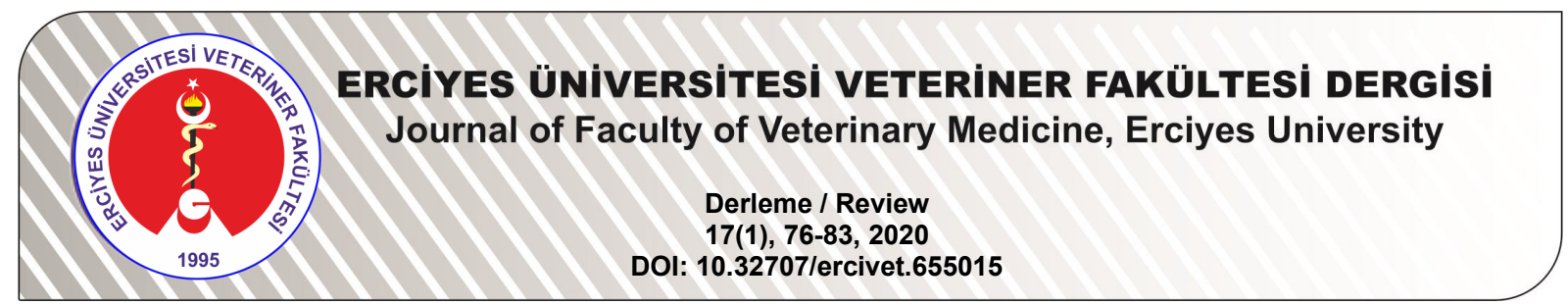

\title{
Kantitatif RT-PCR (RT-qPCR) Çalışmalarında Uygun Housekeeping Genlerin (HKGs) Seçimi ve Validasyonu
}

\author{
Özgecan KORKMAZ AĞAOĞLU, Özge SIDEKLI
}

Burdur Mehmet Akif Ersoy Üniversitesi, Veteriner Fakültesi Zootekni Anabilim Dalı, Burdur-TÜRKIYE

Sorumlu Yazar: Özgecan KORKMAZ AĞAOĞLU; E-posta: ozgecanagaoglu@mehmetakif.edu.tr; ORCID: 0000-0002-74141725

Atıf yapmak için: Korkmaz Ağaoğlu Ö, Sidekli Ö. Kantitatif RT-PCR (RT-qPCR) çalışmalarında uygun housekeeping genlerin (HKGs) seçimi ve validasyonu. Erciyes Üniv Vet Fak Derg 2020;17(1): 76-83.

Özet: Gen ekspresyon çalışmalarında farklı deneysel veya klinik koşullar altında genlerin ekspresyon seviyelerinin karşılaştırılması için kullanılan en yaygın teknik Kantitatif Gerçek Zamanlı Polimeraz Zincir Reaksiyonu (RT-qPCR)'dur. RT-qPCR'da güvenilir sonuçlar elde etmek için verilerin housekeeping genler (HKG) ile normalizasyonunun yapılması gerekmektedir. Bununla birlikte; çalışma tasarımına uygun en stabil HKG'nin kullanılması, çalışma sonuçlarının güvenilirliğini artırmaktadır. Güvenilir veri elde etmek için çalışma tasarımına uygun stabil HKG'nin seçimi ve validasyonu önemli bir adımdır ki bu ekspresyon bazlı çalışmalarda bütünleyici bir adım olmuştur. HKG seçimi için farklı yazılım programları geliştirilmiştir. Normalizasyon için seçilecek en stabil HKG'nin seçilmeden önce deneysel çalışmalar ile dikkatli bir şekilde değerlendirmesinin yapılması gerekmektedir. Bu derlemede; Kantitatif Gerçek Zamanlı PCR Deneylerinin Yayınlanması için Asgari Bilgi (MIQE), HKG'lerin genel özellikleri, RT-qPCR çalışmalarında kullanımları ile çalışma dizaynına göre en uygun ve stabil olan HKG'lerin seçimi ve validasyonu hakkında bilgiler özetlenmiştir.

Anahtar kelimeler: Gen ekspresyonu, housekeeping gen, kantitatif RT-PCR, referans gen

Selection and Validation of Suitable Housekeeping Genes (HKGs) in Quantitative RT-PCR (RT-qPCR) Studies Summary: The quantitative Real-time Polymerase Chain Reaction (RT-qPCR) is the most common technique used to compare the expression levels of genes under different experimental or clinical conditions. Data should be normalized with housekeeping genes (HKGs) to obtain reliable results in RT-qPCR. Likewise, the use the most stable and suitable HKG for the study design improves the reliability of the study results. The selection and validation of a stable HKG according to the study design to obtain reliable data is an essential and integral step in expression-based studies. The several software programs have been developed for HKG selection. The most stable HKG to be selected for normalization needs to be carefully evaluated by experimental studies before selection. In this review, summarized Minimum Information for Publication of Quantitative Real-Time PCR Experiments (MIQE), characteristics of HKGs, selection and validation of most suitable and stable HKGs according to study design and, usage in RT-qPCR.

Key words: Gene expression, housekeeping gene, quantitative RT-PCR, reference gene

\section{Giriş}

Çok hücreli organizmalara ait doku ve organlar birbirinden farklı fenotipik özelliklere sahip olmalarına rağmen benzer gen kümelerine sahiptirler. Doku ve organlarda ki bu fenotipik farklılıklar ilgili genlerin ekspresyon profillerinin dokuya spesifik olarak düzenlenmesi ile ortaya çıkmaktadır (Goldman, 2001). Doku ve organlardaki gen ekspresyonları Northern Blot, İnsitu Hibridizasyon, Kantitatif Gerçek Zamanlı Polimeraz Zincir Reaksiyonu (RT-qPCR) ve Mikroarray teknolojisi gibi çeşitli analiz yöntemleri ile gerçekleştirilmektedir (Goldman, 2001; Segundo-Val ve SnazLozano, 2016). Kantitatif gen ekspresyon analizlerinde kullanılan bu analiz yöntemleri arasında bir gene ait hedeflenen mRNA'nın yüksek duyarlılıkta belirlenebilmesi, hedef bölge çoğaltımı ve kantitatif belirleme aşamasının tek bir cihaz ile yapılabilmesi yönünden en yaygın olarak kullanılan yöntem RT-qPCR'dır

Geliş Tarihi/Submission Date : 15.04.2019 Kabul Tarihi/Accepted Date : 23.07.2019 ve gen ekspresyon analizlerinde kullanılan doğru, hızlı ve hassas bir tekniktir (Jarczak ve ark., 2014; Tilli ve ark., 2016). Bunun yanında; gen ekspresyonundaki nispi değişikliklerin eş zamanlı izlenmesini sağlayan ve mRNA ekspresyonu ile ilişkili "altın standart" olarak kabul edilen güçlü bir tekniktir (VanGuilder ve ark., 2008). Geleneksel RNA ölçüm yöntemlerine göre duyarlılığı, geniş dinamik aralığı ve yüksek verim potansiyeli gibi birçok avantajı nedeniyle, biyolojik araştırma alanlarında çeşitli gen ekspresyon profillerinin analizinde önemli yaklaşım biçimidir (Fleige ve Pfaffl, 2006; Livak ve Schmittgen, 2001). Bununla birlikte; oldukça spesifik ve hassas ölçümler yapmasına karşın, hedeflenen genlerin ekspresyon seviyelerinin analizinde başlangıç numune miktarı ile incelenen numune miktarı arasında ki değişkenlikler, RNA'nın yapısal bütünlüğünün zayıf olması ve PCR etkinliği değerlerindeki farklılıklardan kaynaklanan sorunlar ile karşılaşılmaktadır. Bu tür sorunlar örneklerin farklı zaman aralıklarında ve farklı bireylerden ve/veya doku örneklerinden elde edilmesi ile artmak- 
tadır. Doku ve/veya organda gen ekspresyon analizlerinde karşılaşılan sorunların ortadan kaldırılması ve güvenirliğinin arttırılması için qPCR deneylerinde dikkat edilmesi gereken asgari standartları konu alan bir dizi kurallar (MIQE) ortaya konmuştur. MIQE standartları; DNA mikroarray analizi, proteomik çalışmalar, genom sekanslama, RNA interferans ve metabolomik çalışmalar ile birlikte MIBBI (Minimum Information for Biological and Biomedical Investigations; Biyolojik ve Biyomedikal Araştırmalar için Minimum Bilgi) çatısı altında koordine edilen bir modeldir (Bustin ve ark., 2009). MIQE standartları gereği elde edilen gen ekspresyon ürünlerinin analizinde meydana gelebilecek sorunların en aza indirgenebilmesi için genlerin uygun referans genler ile normalizasyonunun yapılması gerektiği bildirilmiştir (De Spiengelaere ve ark., 2015). Normalizasyon; güvenilir bir qPCR analizinin temel bileşenidir ki bu işlem izolasyon, ters transkripsiyon ve amplifikasyonun verimliliğindeki değişiklikleri ortaya koymaktadır ve böylece farklı örnekler arasında mRNA konsantrasyonlarının karşılaştırılmasını sağlamaktadır. Referans genler veya bir diğer adı ile Housekeeping genler (HKGs); hücrelerin fonksiyonel rollerinden bağımsız olarak, bir hücrenin varlığı için gerekli olan genlerdir (Eisenberg ve Levanon, 2003). Bu nedenle; bir organizmanın tüm hücrelerinde doku tipine, gelişim evresine, hücre döngüsüne veya dış sinyallerine bakılmaksızın normal koşullar altında da eksprese olmaktadırlar (Sikand ve ark., 2012). HKG'ler bu avantajlı özelliklerinden dolayı çeşitli deneysel ve sayısal veri araştırmalarında yaygın olarak kullanım alanı bulmuştur (Sikand ve ark., 2012; Tilli ve ark., 2016). Son zamanlarda yapılan çalışmalar ile birlikte housekeeping genlerin ekspresyon seviyelerinin; gene, hücre tipine ve deneysel koşullarına bağlı olarak değişebildiği ortaya konmuştur. Örneğin; en sık kullanılan housekeeping genlerden biri olan GAPDH'ın doku tipine (Sullivan-Gunn ve ark., 2011), metabolik sürece (Gong ve ark., 2016) veya belirli çalışma koşullarına (Mahoney ve ark., 2004) bağlı olarak stabil olmadığı ortaya konmuştur. $\mathrm{Bu}$ nedenle; çalışma tasarımında ilgili hücrelerde normalizasyon için kullanılacak genin stabilitesinin belirlenmesi herhangi bir hedef genin ekspresyonunun doğru analizi için bir ön koşuldur (Panina ve ark., 2018). Normalizasyon; hedeflenen genlerin mRNA ekspresyon seviyelerinin referans genlere oranlanması ile ortaya konan verileri içermektedir. Referans genlerin mRNA'ları stabil bir şekilde eksprese olmalı ve oranları, numunelerde bulunan toplam mRNA miktarlarıyla pozitif bir korelasyon göstermelidir. Çalışma tasarımına veya fizyolojik duruma yanıt olarak numuneler arasında ekspresyon seviyeleri sabit olan iç kontrol genlerin (ICG'ler) veya referans genlerin (RG'ler) kullanılması, transkripsiyon verilerinin varyasyonun kontrol altına alınabilmesi için kullanılan en etkili yöntem olarak kabul edilmektedir (Kaur ve ark., 2018). Uygun HKG'lerin araştırılmakta olan her doku tipi ve qPCR veri analizinden önce doğrulanması gerekir (Klatte ve Bauer, 2009). Gen ekspresyon verilerinin hatalı yorumlanmasının önlenebilmesi için, birden fazla HKG'nin kullanılması gerektiği önerilmektedir (Chervoneva ve ark., 2010; Vandesompele ve ark., 2002).

Bu derlemede; Kantitatif Gerçek Zamanlı PCR Deneylerinin Yayınlanması için Asgari Bilgi (MIQE), HKG'lerin genel özellikleri, RT-qPCR çalışmalarında kullanımları ile çalışma dizaynına göre en uygun ve stabil olan HKG'lerin seçimi ve validasyonu hakkında bilgiler özetlenmiştir.

\section{Kantitatif Gerçek Zamanlı PCR Deneylerinin Yayınlanması için Asgari Bilgi (MIQE)}

MIQE; qPCR yönteminin yeniden yapılandırılmasını ve deneysel ayrıntıların, veri analizlerinin ayrıntılı denetimini sağlamaktadır. qPCR analizleri ile doğru ve güvenilir sonuçların alınabilmesi için bu kuralların dikkate alınmasının gerekli olduğu bildirilmektedir (Bustin ve ark., 2010). qPCR yöntemini tanımlayan dört ana standardizasyon adımı bulunmaktadır ki bunlar; çalışmanın tasarımı, teknik detaylar, analiz yöntemleri ve istatistik analizlerden oluşmaktadır (Şekil 1).

\section{Çalışmanın Tasarımı}

qPCR çalışmalarında genellikle oldukça düşük verimli ve farklı örneklem tipinde çok çeşitli hedeflerin analizi gerçekleştirilmektedir. Ele alınması gereken ana parametreler testin analitik duyarlılığı ve özgüllüğü ile ilgilidir. Bu bağlamda testin kaç tane hedef bölgeyi algılayabileceği ve kontrollerin çalışma ile ilişkili sonuçlarda doğruluğu önceden belirlenmeli ve öngörülmelidir (Bustin ve ark., 2010).

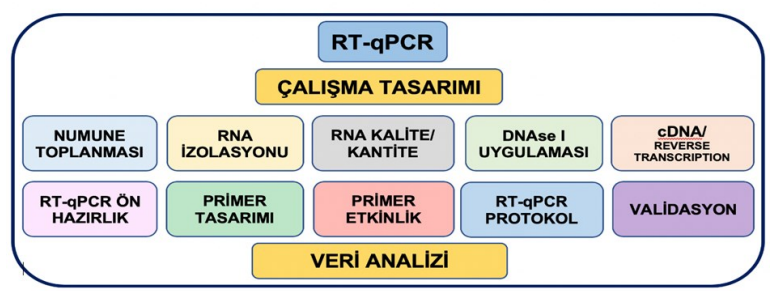

Şekil 1. MIQE'de tanımlanan dört ana standardizasyona göre RT-qPCR yönteminin iş akışı

\section{Teknik Detaylar}

Tasarlanan çalışmada; numunelerin toplanması ve saklanması oldukça kritik bir aşamadır (Bustin ve ark., 2009). Bu aşama boyunca oldukça dikkatli davranılmalı ve numuneler soğuk zincirde taşınmalıdır.

Nükleik asit analizleri için toplanan örnekler için en sık kullanılan saklama yöntemleri arasında "dondurma" yöntemi bulunmaktadır. Ayrıca numunelerden kaliteli RNA elde etmek için RNAse aktivitesi 
mümkün olduğunca çabuk önlenmelidir. Bunun için sıvı azotta ani dondurma, fenol veya kontrol edilen $\mathrm{pH}$ ve çevre sıcaklığındaki dokuların sulu sülfat tuzu çözeltilerinde (amonyum sülfat gibi) saklanması veya taşınması önerilebilir. Sulu sülfat tuzu çözeltileri RNAse'ların ve diğer çözünmüş proteinlerin çökelmesine neden olmaktadır. Bu saklama tekniği; ticari olarak temin edilebilen RNA laters çözeltisinin temelini oluşturmaktadır. Alınan numuneler TRIZOL içerisine konularak $-80{ }^{\circ} \mathrm{C}$ 'de RNA saflaştırma işlemine kadar bekletilebilir (Nolan ve Bustin., 2008). Saflaştırma işleminden sonra; RNA bir diğer işlem aşamasına kadar $-80{ }^{\circ} \mathrm{C}$ 'de saklanabilir (Hashemipetroudi ve ark., 2018). İkinci en kritik aşama; RNA izolasyon aşamasıdır. RNA izolasyonunun etkinliği; numunenin homojen yapıda olup olmadığı, numune tipi, yoğunluğu ve fizyolojik durumuna (örneğin, sağlıklı, kanserli veya nekrotik) bağlı olarak değişebilmektedir. İzole edilen numunelerdeki RNA miktarı önemlidir. Bu nedenle; elde edilen RNA'nın kalite ve kantite kontrolleri yapılmalıdır. RNA kalite kontrolü; RNA saflığı ve RNA bütünlüğünün analizini kapsamaktadır. RNA saflığının belirlenmesi; NanoDrop veya diğer hassas spektrofotometreler kullanılarak fotometrik olarak ölçülebilmektedir. Bu değerlendirme yönteminde; optik yoğunluk (OD) farklı dalga boyları ile saptanmaktadır. Bu dalga boylarından $230 \mathrm{~nm}$; farklı kontaminant maddelerin maksimum absorbans değerini, $260 \mathrm{~nm}$; nükleik asit kontaminasyonunun maksimum absorbans değerini, $280 \mathrm{~nm}$; protein-fenol kontaminasyonun maksimum absorbans değerini ve $320 \mathrm{~nm}$ ise; farklı kontaminant maddelerin maksimum absorbans değerini işaret etmektedir. OD260/280 oranı RNA saflığının belirlenmesi için tercih edilmektedir (Becker ve ark., 2010). OD260/280 oranı, RNA saflığı için gösterge olarak kullanılır. Gen ekspresyon ölçümleri için 1.8'den yüksek bir oranın uygun olduğu varsayılmaktadır (Nolan ve Bustin, 2008; Becker ve ark., 2010). Nükleik asitlerin kalite kontrolü; ribozomal RNA (rRNA) alt birimlerinin farklı fraksiyonlarını (5S, 18S, 28S) ayırmak için agaroz jel elektroforezi kullanılarak yapılmaktadır. İyi kalitedeki RNA için $28 S / 18 S$ oranı 2.0 olarak kabul edilmektedir (Becker ve ark., 2010). Total RNA bütünlüğünün (RNA integrity) kontrolü için; farklı otomatize sistemler kullanılmaktadır. Bu sistemler ile RNA bütünlük değeri (RNA Integrity Number; RIN) ve RNA kalite indeksi (RNA Quality Index; RQI) değerleri belirlenmektedir (Nolan ve Bustin, 2008; Becker ve ark., 2010). Bu değerler; 1 ile 10 arasında değişmektedir. Kaliteli bir RNA eldesi için bu değerin en az 8 olması istenmektedir (Nolan ve Bustin, 2008). Bununla birlikte; farklı numuneleri karşılaştırırken yaklaşık olarak aynı miktarda RNA kullanılması önerilmektedir (Bustin ve ark., 2010; Huggett ve ark., 2005). Uygun sulandırma işlemlerinden sonra; olası DNA kontaminasyonu için cDNA analizinden önce DNAse I ile DNA digestion işlemi uygulanmalıdır (Bustin ve ark., 2009). DNAse I ile muameleden sonra, saflaştırılmış RNA numunesinin kalite kantite kontrolleri yanında, spesifik ribozomal DNA (rDNA) pri- merleri ile test edilmeleri sonuçların güvenilirliği açısından gereklidir. Analiz sırasında DNA içermeyen RNA numunelerinde amplifikasyon sinyali tespit edilmemelidir. Buna dayanarak, qPCR'de bir amplifikasyon sinyali tespit edilirse veya agaroz jelde bir bant tespit edilirse bunun DNA kontaminasyonundan kaynaklandığı sonucuna varılabilir (Hashemipetroudi ve ark., 2018). Bu işlemlerden sonra; cDNA sentezi yapılmalı ve uygulanan protokoller ayrıntılı bir şekilde açıklanmalıdır. Ayrıca elde edilen RNA'nın cDNA'ya dönüştürülmesi yani ters transkripsiyon aşamasının iki veya üç kez tekrarlanması önerilmektedir (Ståhlberg ve ark., 2004). RT-qPCR için hedeflenen primer dizileri, amplikon için veritabanı erişim numaraları, herhangi bir boya ve/veya modifiye edilmiş bazların bilgileri ve konumlarının kontrol edilmesi önemlidir (Bustin ve ark., 2010). Çalışmada kullanılacak olan primer dizilerinin özgüllüğü; jel elektroforez ve erime profilleri kullanılarak doğrulanmalı, erime sıcaklıkları ve döngü sayısı (Cycle threshold; Ct) belirlenmelidir. Ayrıca çalışmada kullanılacak her bir primerin etkinlik (primer efficiency) değerleri, özgüllüğü ve duyarlııı̆ı belirlenmelidir (Bustin ve ark., 2010b). RT-qPCR'ın optimizasyonunun yanı sıra istenmeyen amplifikasyon ürünlerinin oluşumunun önlenebilmesi için bazı kontrol ürünleri veya kalibratörler kullanılabilir (Bustin ve ark., 2010). Kontrol ürünleri PCR'da oluşan ikincil yapıları tespit ederek, kullanılan reaksiyonda az miktardaki PCR ürünlerini saptamaktadır. Kalibratörler; sentetik RNA veya DNA oligonükleotitleri, plazmid DNA yapıları, plazmidlere klonlanmış cDNA, in vitro kopyalanan RNA, referans RNA havuzları, spesifik biyolojik numunelerden RNA veya DNA gibi saflaştırılmış hedef moleküllerden tercih edilebilir (Bustin ve ark., 2009).

qPCR analizlerinin doğruluğu ve güvenirliği qPCR'nin etkinliği ile ilişkilidir. qPCR etkinliği; özellikle hedef genin mRNA ekspresyon seviyesinin referans gen ile karşılaştırıldığı zaman anlaşılmaktadır. Bu doğrultu$\mathrm{da}$; örnekler arasındaki konsantrasyon farkının ortaya konmasında, dolayısı ile qPCR verilerinin analizinde yaygın olarak " 2 - $\Delta \Delta \mathrm{Ct}$ " yöntemi kullanılmaktadır (Bustin ve ark., 2009; Livak ve Schmittgen, 2001). 2 $\Delta \Delta \mathrm{Ct}$ metodu; bir kalibratör yardımı ile hedef genin ve HKG'nin karşılaştırılması yapılarak oransal gen anlatım düzeylerinin aritmetik formülle hesaplanması temeline dayanmaktadır (Livak ve Schmittgen, 2001). Hedeflenen genin HKG ile normalizasyonu için reaksiyonun etkinliği $(E)$ belirlenmeli ve genler arasındaki Ct değerlerine dayalı farklılıklar göz önünde bulundurulmalıdır. Etkinlik değerleri arasındaki fark $2^{-\Delta \Delta \mathrm{Ct}} \mathrm{me}-$ todu ile saptanmaktadır (Livak ve Schmittgen, 2001). Bununla birlikte, referans gen ile çalışılan genler arasında benzer PCR etkinliğine $2^{-\Delta \Lambda C t}$ metodu ile nadiren ulaşılmaktadır, bu nedenle genler arasındaki etkinlik farkını azaltan başka bir matematiksel model geliştirilmiştir. Referans gen ile normalizasyonu sağlayan matematiksel model; R: ( $\mathrm{E}_{\text {çalsşlan gen) }}$ (Ct çallşıllan gen (kontrol-ornek) $/\left(\mathrm{E}_{\text {kontrol gen })}{ }_{\Delta \mathrm{Ct} \text { kontrol gen (kontrol-örnek) }}\right.$ olarak bildi- 
rilmiştir (Pfaffl, 2001). PCR amplifikasyon ürünlerinin etkinliği, kalibrasyon eğrisi ile göreceli olarak ortaya konmaktadır. Kalibrasyon eğrisinin $\left\langle 10^{1}\right.$ ile $\left.10^{10}\right\rangle$ dinamik sulandırma aralığında olması istenmektedir. $\mathrm{Bu}$ doğrultuda; kalibrasyon eğrisi ile ilişkili regresyon katsayısı hesaplanmaktadır (Pfaffl, 2001). Bu regresyon katsayısı; PCR'nin logaritmik artış bölümünün eğimine eşit olmakla birlikte amplifikasyon ürünlerinin etkinliği ile de ilişkilidir (Burns ve ark., 2005). Kalibrasyon eğrisinin eğimi $E=10^{(-1 / \text { eğim })}$ ile hesaplanmakta ve optimal $\mathrm{qPCR}$ etkinliğin $\mathrm{E}=1.60$ ile 2.10 olması istenmektedir (Pfaffl ve ark., 2002). Ayrıca mutlak gen ekspresyon analizinde kullanılan referans gen ve primerlerin etkinliğinin belirlenmesinde bir dizi dilüsyon serilerinin oluşturulması ve değerlendirilmesi çalışma sonucunun doğruluğunu ve güvenirliğinin arttırılması yönünden önerilmektedir (Bustin ve ark., 2009).

qPCR analizinin temel bir bileşeni olan normalizasyon ile izolasyon, ters transkripsiyon ve amplifikasyon ürünlerinin etkinlik değerleri arasında değişikliklerin kontrol edilebilmesinin yanısıra farklı örnekler arasındaki mRNA konsantrasyonları da karşılaştırılabilmektedir. Bu doğrultuda normalizasyon için referans genler yani HKG'ler tercih edilmektedir (Bustin ve ark., 2009; Ståhlberg ve ark., 2004). Normalizasyon için kullanılacak olan referans genler çeşitli deneysel çaIışmalar ile ilgili doku ve/veya organ için uygunluğu belirlenmelidir. Ayrıca kullanılması planlanan HKG'lerin üçten daha az olması önerilmemektedir (Huggett ve ark., 2005).

\section{HKG'ler ve HKG'lerin Genomik Yapısı}

Bütün doku ve/veya organlarda eksprese olan HKG'ler; hedeflenen gen diziliminden farklı bir genomik organizasyona sahiptir (Goldman, 2001). Ayrıca bu genler; DNA sentezi, protein sentezi ve transkripsiyon gibi hücresel metabolik olaylarda da rol oynamaktadır (Farre ve ark., 2007). HKG'lerin dokuya spesifik eksprese olan genlerden farklı bir promotör bölgelerine sahip oldukları ve $\mathrm{CpG}$ adaları ile ilişkili oldukları bildirilmiştir (Farre ve ark., 2007; Goldman, 2001). Diğer genlerin aksine HKG'lerin promotör bölgelerinde TATA ve CAAT kutusu bulunmamaktadır, bunun yerine promotör bölgelerinde GC'ce zengin diziler içermektedirler. Promotör bölgelerinde bulunan GC dizileri, TATA kutusu gibi transkripsiyonun başlatılmasından sorumlu olmakla birlikte, Sp1 gibi GC dizilerini tanıyan transkripsiyon faktörlerin promotör bölgelerine bağlanmasını sağlamaktadır (Goldman, 2001). Ayrıca farklı genomik organizasyona sahip organizmalarda yapılan çalışmalarda referans genlerin kısa ve uzun intron ve ekzon bölgelerine, tüm genoma dağılmış tekrar dizilerine, düşük korunumlu promotör bölgelerine sahip oldukları, ayrıca histon proteinlerine karşı daha az ilgi gösterdikleri saptanmıştır (Farre ve ark., 2007).
HKG'ler kantitatif analizlerde yaygın olarak kullanımaktadır (Tilli ve ark., 2016). Yapılan çalışmalarda yaygın olarak kullanılan HKG'lerin; glisealdehit-3fosfat dehidrojenaz (GAPDH), Beta aktin ( $\beta$-Aktin), TATA bağlanma proteinleri (TBP), hipoksantinguanidin fosforibozil transferaz (HPRT), tubulinler, siklofilin (CyP), albümin, 18S rRNA ve $28 S$ rRNA olduğu bildirilmektedir.

HKG'lerin ekspresyon seviyelerinin türe, doku tipine, organizmanın gelişim dönemine, hastalık ve enfeksiyon durumuna göre değiştiği ortaya konmuştur. Örneğin; GAPDH yapılan bazı çalışmalarda en stabil gen olarak bildirilmesine rağmen; bu HKG'nin eksternal ve internal faktörlerden önemli ölçüde etkilendiği gösterilmiştir. Öyle ki; Barber ve ark. (2005) insanlarda 72 farklı doku örneğinde GAPDH mRNA ekspresyon seviyesinin önemli ölçüde değiştiğini bildirmişlerdir. Incelenen doku örneklerinde; GAPDH'nin iskelet kaslarında en yüksek, meme dokusunda ise en düşük ekspresyon profiline sahip olduğu ortaya konmuştur. Morfolojik değişikliklere uğrayan doku ve farklı gelişim evrelerini içeren çalışmalarda $\beta$-aktin'lerin, HKG olarak kullanımları önerilmemektedir (Zhong ve Simons, 1999). RT-qPCR analizlerinde yaygın olarak kullanılan HKG'lerden biri olan ribozomal RNA'ların da çoğu hücre tipinde ekspresyon seviyelerinin yüksek olmasından dolayı, bazı gen ekspresyon analizlerinde HKG olarak kullanılmaları önerilmemektedir (Kozera ve Rapacz, 2013). Örneğin; hücre oksidatif stres altındayken 18S rRNA ekspresyonlarının azaldığı (Hayashi, 2014); 28S rRNA'nın ise hipoksik koşullar altında ekspresyonunun; GAPDH, $\beta$-aktin ve CyP'ye göre daha stabil olduğu ortaya konmuştur (Zhong ve Simons, 1999). Elde edilen bu verilerin normalizasyon için tek bir referans genin kullanılmasının çalışma sonuçlarının hatalı yorumlanmasına neden olacağını göstermektedir (Vandesompele ve ark., 2002). Bu nedenle; yapılacak olan çalışmada iki veya daha fazla referans genin tanımlanması ve kullanılması önerilmektedir (Bustin ve ark., 2009). Bu anlamda; evcil memeli hayvanlarda ve insan gibi çeşitli türlerin farklı dokularında en stabil HKG'lerin belirlemesi üzerine çeşitli çalışmalar yapılmaktadır. Uddin ve ark. (2011) yenidoğan, genç ve yetişkin domuzlardan toplanan farklı doku (servikal ve mezenterik lenf bezleri, duodenumdan bağırsak mukozası, jejunum ve ileum, mide, karaciğer, dalak, timus, akciğer, böbrek, kalp ve kulaktan alınan dokular) örneklerinde yaygın olarak kullanılan dokuz tane referans genin (B2M, BLM, GAPDH, HPRT1, PPIA, RPL4, SDHA, TBP ve YWHAZ) mRNA ekspresyon stabilitesini araştırmışlardır. Bu amaçla; geNorm, NormFinder ve BestKeeper yazılımlarını kullanmışlardır. geNorm yazılımı ile yapılan analizlerde; yenidoğan ve yetişkin domuzlarda RPL4, PPIA ve YWHAZ'ın yüksek stabilite gösterdiği, genç domuzlarda ise B2M, YWHAZ ve SDHA'nın yüksek stabilite gösterdiği belirlenmiştir. Tüm durumlarda; GAPDH'nin en az stabilite gösterdi- 
ği bildirilmiştir. Cinar ve ark. (2012) lipopolisakkarit ve lipoteikoik asite karşı oluşan immun yanıtta görev alan domuz alveolar makrofajlarında gen ekspresyon çalışmaları için uygun referans genlerin değerlendirilmesi için yaygın olarak kullanılan B2M, BLM, GAPDH, HPRT1, PPIA, RPL4, SDHA, TBP and YWHAZ HKG'lerin stabilitesini değerlendirmek için üç farklı algoritma (geNorm, Normfinder ve BestKeeper) uygulamıştır. Tüm genlerin mRNA ekspresyon seviyelerinin, stimülasyon tipinden ve stimülasyon süresinden etkilendiği belirtilmiştir. geNorm yazılımı, SDHA, B2M ve RPL4'ün, stimülasyon grubundan bağımsız olarak yüksek ekspresyon stabilitesi gösterdiğini, SDHA, YWHAZ ve RPL4'ün, stimüle edilmemiş kontrol grubunda yüksek stabilite gösterdiği belirlenmiştir. Tüm durumlarda; GAPDH'nin en az stabilite gösterdiği belirlenmiştir. NormFinder ile yapılan analizlerde SDHA'nın tüm gruplarda en stabil gen olduğunu ortaya konulmuştur Ayrıca, geNorm yazılımı sonucu elde edilen verilerden; en kararlı üç genin (SDHA, YWHAZ ve RPL4) geometrik ortalamasının, gen ekspresyonu çalışmasının doğru normalize edilmesi için uygun kombinasyon olacağını önermişlerdir. Du ve ark. (2016) piyometralı ve sağlıklı köpek uterus doku örneklerinde GeNorm, Normfinder, BestKeeper ve RefFinder yazılım programlarını kullanarak en stabil referans geni belirlemek için yedi farklı HKG (18SrRNA, ACTB, B2M, GAPDH, HPRT, RPL13A ve YWHAZ)'nin stabilitesini değerlendirmişlerdir. Sonuçlar incelendiğinde; YWHAZ dışında diğer HKG'lerin piyometra ve sağlıklı dokulardaki ekspresyon stabilitelerinin farklı olduğunu saptamışlardır. Agaoglu ve ark. (2017) tedavi amacıyla presynch-10+ovsynch uygulanan repeat breeder ineklerin endometriyumlarında Toll (TLR-2, TLR-4) ve Nod (NOD-1, NOD2, IPAF ve NALP3) benzeri reseptörlerin ekspresyon seviyelerinin araştırdıkları çalışmalarında; referans genin belirlenmesi amacıyla (B2-GAPDH, Beta-Aktin, HPRT1, YHWAZ, SDHA, SUZ12, TUBA1, 18S) geNorm, NormFinder ve BestKeeper algoritmalarından yararlanarak en uygun ve stabil referans geni YHWAZ olarak belirlemişlerdir. Korkmaz Agaoglu ve ark. (2017) kedilerde gebeliğin farklı dönemlerinde IGF ailesinin (IGF-1, IGF-2, IGF1R, IGF2R, IGFBP1, IGFBP2, IGFBP3, IGFBP4, IGFBP5 ve IGFBP6) uterustaki ekspresyon seviyelerinin nasıl bir değişim gösterdiğini araştırdıkları çalışmalarında; 8 farklı HKG (GAPDH, 18S, TUBA1, UBB, HPRT1, Beta Aktin, SDHA, YWHAZ)'i geNORM, NormFinder ve BestKeeper algoritmaları ile değerlendirmişlerdir. Çalışma tasarımına göre en uygun ve stabil referans genin GAPDH olduğunu bildirmişlerdir. Kaur ve ark. (2018) mandalarda on adet aday referans gen (GAPDH, ACTB, UXT, RPS15, RPL4, RPS9, RPS9, RPS23, HMBS, $\beta 2 M$ ve EEF1A1)'in böbrek, dalak, karaciğer, kalp, bağırsak, ovaryum, akciğer, kas, beyin, deri altı yağı ve testislerde stabilitesini analiz etmişlerdir. Genorm (UXT/RPS9> RPL4> RPS23> EEF1A1> $A C T B>H M B S>G A P D H>B 2 M>R P S 15)$, Normfin- der (UXT> RPS23> RPL4> RPS9> EEF1A1> $H M B S>A C T B>\beta 2 M>G A P D H>R P S 15)$ ve BestKeeper (RPS9> RPS23/UXT> RPL4> GAPDH> EEF1A1> ACTB> HMBS $>\beta 2 M>R P S 15$ ) programları temel alınarak yapılan çalışmada RPS23, RPS9, RPL4 ve UXT genlerinin mandalarda çeşitli doku örneklerinde transkripsiyonel verilerin normalizasyonunda kullanılabilecek en stabil HKG'ler olarak tanımlanmışlardır.

\section{HKG'lerin Seçimi}

Kantitatif gen ekspresyon çalışmalarında; dokuya spesifik, ekspresyon profili değişmeyen tek bir referans genin tanımlanmasında ki zorluklardan dolayı, birden fazla referans gen kullanılarak en stabil genin belirlenmesi önerilmektedir (Bustin ve ark., 2009). Bu doğrultuda; kantitatif analizlerde kullanılacak olan bir genin güvenilir HKG olarak kabul edilebilmesi için; eksternal ve internal faktörlerden minimum düzeyde etkilenmesi, organizmanın fizyolojik durumuna ve farklı doku tipleri arasındaki ekspresyon seviyelerindeki değişkenliğin minimal seviyede olması istenmektedir. Bu nedenle; dokularda ve hücrelerde aynı biyokimyasal sinyal yollarına sahip olmayan ve farklı fenotipik fonksiyonlarda görev alan genler tercih edilmelidir. Ayrıca seçilecek HKG'lerin, hedeflenen gen ile benzer/yakın döngü sayısında (Ct) eksprese olması önerilmektedir (Chervoneva ve ark., 2010). HKG'lerin seçiminde hedeflenen genin ekspresyonunun, referans gene göre daha düşük veya daha yüksek Ct değerinde olduğunun saptanması, kantitatif analiz sonuçlarının hatalı yorumlanmasına neden olabilmektedir (Cross ve ark., 1994). Örneğin; Hipoksantin-guanin fosforibozil transferaz (HPRT) geninin çeşitli hücre ve dokularda ekspresyon seviyesinin düşük olduğu belirlenmiştir. Bundan dolayı ekspresyon seviyesi düşük olan hedef genlerin, normalizasyonu için tercih edilmesi gerektiği önerilmiştir (Bär ve ark., 2009). Ayrıca, HKG'lerin promotör bölgelerinin düşük korunumlu olmasından dolayı çeşitli eksternal (radyasyon, çeşitli kimyasal maddeler ve mutasyon gibi) ve internal (farklı hücre ve/veya doku tipi gibi) faktörlere bağlı olarak ekspresyon seviyelerinin değiştiği ortaya konmuştur (Cross ve ark., 1994; Goldman, 2001; Zhong ve Simons, 1999). Örneğin; Blomberg ve ark. (1987) insanlarda referans gen olarak kullanmış oldukları $\beta$-aktin geninin farklı tümöral hücrelerde ekspresyonlarının değiştiğini bildirmişlerdir. Zhong ve Simons, (1999) GAPDH geninin ekspresyon seviyesinin hücrelerde hipoksi, insülin, deksametazon, mitojenler ve EGF dahil olmak üzere çeşitli uyarıcılara yanıt olarak değiştiğini bildirmişlerdir. Benzer şekilde; HKG genlerden biri olan melallotiyoninin ağır metallerin bulunduğu durumlarda ekspresyon seviyesinin arttığı saptanmıştır (Goldman, 2001). Bu nedenle; kantitatif analiz çalışmalarında kullanılması planlanan referans genlerin çalışmaya uygun seçilmesi ve değerlendirilmesi gerekmektedir. Çalışma tasarımına göre; en uygun ve stabil housekeeping 
genin seçimi için çeşitli istatistiksel yaklaşım metotları bulunmaktadır. Bu yaklaşım metodları ile bir veya birden fazla referans genin optimal seçiminde; GeNorm (Vandesompele ve ark., 2002), KH Sadek (Sadek ve ark., 2012), Normfinder (Andersen ve ark., 2004), BestKeeper (Pfaffl ve ark., 2004) ve RefFinder (Xie ve ark., 2011) gibi çeşitli algoritmalar kullanılmaktadır (Şekil 2).

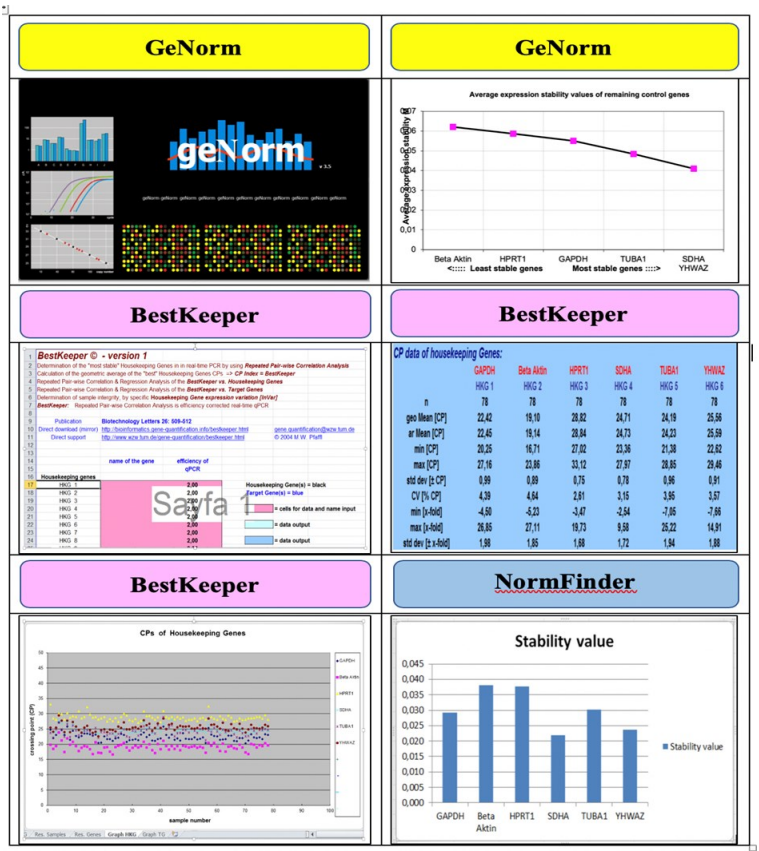

Şekil 2. Referans gen seçiminde kullanılan yazılımlar [GeNorm (Vandesompele ve ark., 2002), BestKeeper (Pfaffl ve ark., 2004), Normfinder (Andersen ve ark., 2004)] ve örnekler (Agaoglu ve ark., 2017; Korkmaz Agaoglu ve ark., 2017)

Bunlardan en yaygın olarak kullanılan metot; GeNorm isimli bilgisayar algoritmasıdır. Bu yazılım programı; HKG'yi belirli bir dokuda stabilitesine (M) göre sıralamaktadır. Yazııım programında belirlenen $M$ değeri düşük olan genlerin daha stabil olduğu varsayılarak; seçim sırasında ekspresyon stabilitesi daha zayıf olan HKG'ler ardışık olarak ortadan kaldırılmaktadır. Geriye kalan aday HKG'lerin geometrik ortalamaları alınmakta ve hedef genin normalizasyonu için kullanılmaktadır (Vandesompele ve ark., 2002). Bir diğer metot olan KH Sadek analizi; farklı gruplar içerisinde bütün referans genlerin eşik döngü sayıları $(\mathrm{Ct})$ arasındaki değişikliklerin karşılaştırılmasına dayanan bir yaklaşım metodudur (Sadek ve ark., 2012). Normfinder yazılımı ise; aday referans genleri verilen örnek numunedeki ve çalışma tasarımındaki ekspresyon stabilitesine göre sıralamaktadır (Andersen ve ark., 2004). Ayrıca; bu yazılım algoritması hem aday HKG'lerin genel ekspresyon varyasyonlarını hem de örnek setteki alt gruplardaki varyasyon için de stabili- te analizi yapmaktadır. BestKeeper yazılım programı; temel olarak tüm referans genleri çift yönlü bir korelasyon analizine tabi tutarak, aday genlerin stabilitesini ölçmektedir. Bu ölçüm sonucunda en stabil olan HKG'lerin geometrik ortalamaları alınmakta ve sıralama işlemi yapılmaktadır (Pfaffl, 2001). Son olarak RefFinder; stabil olan genlerin ortalama geometrik oranlarını alarak HKG'leri sıralamaktadır (Xie ve ark., 2011). Referans gen seçiminde kullanılan bu programlar arasından biri veya birkaçı kullanılarak en uygun ve stabil HKG'ler seçilmektedir.

\section{Sonuç}

Gen ekspresyonu analiz yöntemleri çeşitli moleküler araştırmalarda yaygın olarak kullanılmaktadır. Hedef genin mRNA ekspresyon analizlerinde güvenilir sonuçlar elde etmek için; RNA miktarı ve cDNA miktarının getirdiği örnekler arası başlangıç farklılıkları, deneysel hatalar gibi değişkenler karşısında ekspresyonları stabil olan HKG'ler ile normalizasyonun yapılması gerekmektedir. Bu nedenle; farklı doku ve hücre tiplerinde, hedef genlerin ekspresyon düzeyinin kantitatif olarak belirlenmesi amacıyla yapılan çalışmalarda, önce referans olarak kullanılacak en uygun stabil HKG'nin doğru seçilmesi gereklidir. Ayrıca seçilecek HKG için daha önce yapılan pilot çalışmalardan referans alınması gen ekspresyon analizlerinde nispi doğruluğunu artıracaktır. Daha önce belirlenen ve yaygın olarak kullanılan çok sayıda HKG olmasına karşın; yapılan çalışmalar ile birlikte HKG'lerin ekspresyon seviyelerinin türe, doku tipine, organizmanın gelişim dönemine, hastalık ve enfeksiyon durumuna göre değiştiği de ortaya konmuştur. Bu nedenle; HKG'lerin çalışma tasarımına uygun olarak seçilmesi ve değerlendirilmesi gerekmektedir. Çalışmaya uygun bir veya birden fazla referans gen çeşitli istatistiksel yaklaşım metodları kullanılarak seçilmektedir. Bu yaklaşım metodları ile belirlenen HKG'ler, hedeflenen genin ekspresyon seviyesine oranlanarak normalizasyon yapılmaktadır. Bu da çalışmadan elde edilen verilerin güvenirliğini artıracaktır. Sonuç olarak; çalışmalarda kullanılacak HKG'lerin ekspresyon seviyesi ne kadar stabil olursa, hedef genin ekspresyon seviyesinin kantitatif analizi de o kadar güvenilir olacaktır.

\section{Kaynaklar}

Agaoglu AR, Agaoglu OK, Aslan S, Kocamuftuoglu M, Koker A, Cetin Y, Gungor O, Ozturk D, Saatcı $M$. The effects of presynch-ovsynch applications on endometrial Toll and Nod like receptor gene expressions in cows with repeat breeder syndrome (RBS). Turkish Society of Veterinary Gynaecology VII. National-I. International Congress, October, 1518, 2017; Marmaris-Türkiye.

Andersen CL, Jensen JL, Ørntoft TF. Normalization of real-time quantitative reverse transcription-PCR data: a model-based variance estimation approach 
to identify genes suited for normalization, applied to bladder and colon cancer data sets. Cancer Res 2004; 64(15): 5245-50.

Bär M, Bär D, Lehmann B. Selection and validation of candidate housekeeping genes for studies of human keratinocytes-review and recommendations. Jidonline 2009; 129(3): 535-7.

Barber RD, Harmer DW, Coleman RA, Clark BJ. GAPDH as a housekeeping gene: analysis of GAPDH mRNA expression in a panel of 72 human tissue. Physiol Genomics 2005; 21(3): 389-95.

Becker C, Hammerle-Fickinger A, Riedmaier I, Pfaffl MW. mRNA and microRNA quality control for RTqPCR analysis. Methods 2010; 50(4):237-43.

Blomberg J, Andersson M, Faldt R. Differential pattern of oncogene and beta-actin expression in leukaemic cells from AML patients. J Haematol 1987; 65(1): 83-6.

Bogaert L, Van Poucke M, De Baere C, Peelman L, Gasthuys F, Martens A. Selection of a set of reliable reference genes for quantitative real-time PCR in normal equine skin and in equine sarcoids. BMC Biotechnol 2006; 6(24): 1-7.

Burns MJ, Nixon GJ, Foy CA, Harris N. Standardisation of data from real-time quantitative PCR methods - evaluation of outliers and comparison of calibration curves. BMC Biotechnol 2005; 5(31): 113.

Bustin SA, Beaulieu JF, Huggett J, Jaggi R, Kibenge FSB, Olsvik PA, Penning LC, Toegel S. MIQE precis: Practical implementation of minimum standard quidelines for fluorescence based quantitative realtime PCR expreriments. BMC Mol Biol 2010; 11 (74): 1-5.

Bustin SA, Benes V, Garson JA, Hellemans J, Huggett J, Kubista M, Mueller R,T, Pfaffl MW, Shipley GL, Vandesompele J, Wittwer CT. The MIQE Guidelines: Minimum information for publication of quantitive real-time PCR experiments. Clin Chem 2009; 55(4): 611-22.

Bustin SA. Why the need for qPCR publication guidelines?-The case for MIQE. Methods 2010; 50(4): 217-26.

Chervoneva I, Li Y, Schulz S, Croker S, Wilson C, Waldman SA, Hyslop T. Selection of optimal reference genes for normalization in quantitative RTPCR. BMC Bioinforma 2010; 11(253): 1-15.

Cinar MU, Islam MA, Uddin MJ, Tholen E, Tesfaye D, Looft C, Schellander K. Evaluation of suitable reference genes for gene expression studies in porcine alveolar macrophages in response to LPS and LTA. BMC Res Notes 2012; 5(107): 1-14

Cross NC, Lin F, Goldman JM. Appropriate controls for reverse transcription polymerase chain reaction (RT-PCR). Br J Haematol 1994; 87(1): 218.

De Spiengelaere W, Dern-Wieloch J, Weigel R, Schumacher V, Schorle H, Nettersheim D, Bergmann M, Brehm R, Kliesch S, Vandekerckhove L, Fink C. Reference gene validation for RT-PCR, a note on different available software packages. PLoS One 2015; 10(3): e122515.

Du M, Wang YW, Yue PY, Zhou PY, Yao W, Li X, Ding XB, Liu XF, Guo H, Ma WZ. Selection of reference genes in canine uterine tissues. Genet Mol Res 2016; 15(2): 1-14.

Eisenberg E, Levanon EY. Human housekeeping genes are compact. Trends Genet 2003; 19(7): 362 -5 .

Farre D, Bellora N, Mularoni L, Messeguer X, Alba MM. Housekeeping genes tend to Show reduced upstream sequence conservation. Genome Bio 2007; 8(7): RI40

Fleige S, Pfaffl MW. RNA integrity and the effect on the real-time qRT-PCR performance. Mol Aspects Med 2006; 27(2-3): 126-39.

Goldman M. Housekeeping Gene. Brenner S. Miller JH. eds. In: Encyclopedia of Genetics. Academic Press. 2001; pp. 978

Gong S, Schmotzer CL, Zhou L. Evaluation of quantitative real-time PCR as a hepatitis $C$ virus supplementary test after RIBA discontinuation. J Clin Lab Anal 2016; 30(5): 418-23.

Hashemipetroudi SH, Nematzadeh G, Ahmadian G, Yamchi A, Kuhlmann M. Assesment of DNA contamination in RNA samples based on ribosomal DNA. J Vis Exp 2018; 131(22): e55451.

Hayashi R. Gene expression and the impact of antioxidant supplements in the cataractous lens. Preedy VR. ed. Handbook of Nutrition, Diet and the Eye. London: Academic press 2014; pp. 517-24.

Huggett J, Dheda K, Bustin S, Zumla A. Real-Time RT-PCR normalisation; strategies and considerations. Genes Immun 2005; 6(4): 279-84.

Jarczak J, Kaba J, Bagnicka E. The validation of housekeeping genes as a reference in quantitative Real Time PCR analysis: application in the milk somatic cells and frozen whole blood of goats infected with caprine arthritis encephalitis virus. Gene 2014; 549(2): 280-5.

Kaur R, Sodhi M, Sharma A, Sharmi VL, Verma P, 
Swami SK, Kumari P, Mukesh M. Selection of suitable reference genes for normalizastion of quantitative RT-PCR expression data across twelve tissues of riverine buffaloes. PLoS One 2018; 13(3): E01191668.

Klatte M, Bauer P. Accurate Real-time reverse transcription quantitative PCR. Methods Mol Biol 2009; 479(4): 61-77.

Korkmaz Agaoglu O, Agaoglu AR, Ozmen O, Saatcı M, Schäfer-Somi S, Aslan S. Investigation of Insulin -like Growth Factor Gene Family in Cat Uterus During Pregnancy at mRNA and Protein Level. XXth International Congress of the European Veterinary Society for Small Animal Reproduction (EVSSAR). June 29-July 1, 2017; Vienna-Austria.

Kozera B, Rapacz M. Reference genes in real-time PCR. J Appl Genetics 2013; 54(4): 391-406.

Livak KJ, Schmittgen TD. Analysis of relative gene expression data using real-time quantitive PCR and the 2(-Delta Delta C(T)) Method. Methods 2001; 25 (4): 402-8.

Mahoney DJ, Carey K, Fu MH, Snow R, CameronSmith D, Parise G, Tarnopolsky MA. Real-time RTPCR analysis of housekeeping genes in human skeletal muscle following acute exercise. 2004; 18 (2): 226-31.

Nolan T, Bustin S. Procedures for Quality Control of RNA Samples for Use in Quantitative Reverse Transcription PCR. Keen JT Birch L. eds. In: Essentials of nucleic acid analysis: a robust approach. London: The royal society of Chemistry, 2008; pp. 189-207.

Panina Y, Germond A, Masui S, Watanabe TM. Validation of common housekeeping genes as reference for qPCR gene expression analysis during IPS reprogramming process. Sci Rep 2018; 8(1): 8716.

Pfaffl MW, Horgan GW, Dempfle L. Relative expression software tool (REST) for group-wise comparison and statistical analysis of relative expression results in real-time PCR. Nucleic Acids Res 2002; 30(9): e36.

Pfaffl MW, Tichopad A, Prgomet C, Neuvians TP. Determination of stable housekeeping genes, differentially regulated target genes and sample integrity: BestKeeper-Excel-based tool using pair-wise correlations. Biotech Lett 2004; 26(6): 509-15.

Pfaffl MW. A new mathematical model for relative quantification in real-time RT-PCR. Nucleic Acids Res 2001; 29(9): e45.

Sadek KH, Cagampang FR, Bruce KD, Shreeve N,
Macklon N, Cheong Y. Variation in stability of housekeeping genes in endometrium of healthy and polycystic ovarian syndrome women. Hum Reprod 2012; 27(1): 251-6.

Segundo-Val IS, Sanz-Lozano CS. Introduction to the gene expression analysis. Methods Mol Biol 2016; 1434(3): 29-43.

Sikand K, Singh J, Ebron JS, Shukla GC. Housekeeping gene selection advisory: Glyceraldehyde-3Phosphate Dehydrogenase (GAPDH) and $\beta$-Actin are targets of miR-644a. PLoS One 2012; 7(10): e47510.

Ståhlberg A, Hakansson J, Xian X, Semb H, Kubista $M$. Properties of the reverse transcription reaction in mRNA quantification. Clin Chem 2004; 50(3): 509-15.

Sullivan-Gunn M, Hinch E, Vaughan V, Lewandowski $P$. Choosing a stable housekeeping gene and protein is essential in generating valid gene and protein expression results. $\mathrm{Br} \mathrm{J}$ Cancer 2011; 104(6): 1055.

Tilli TM, Castro CS, Tuszynski JA, Carels N. A strategy to identify housekeeping genes suitable for analysis in breast cancer diseases. BMC Genomics 2016; 17(1): 639

Uddin M, Cinar M, Tesfaye D, Looft C, Tholen E, Schellander K. Age-related changes in relative expression stability of commonly used housekeeping genes in selected porcine tissues. BMC Res Notes. $2011 ; 4(441)$ : 1-13.

Vandesompele J, De Preter K, Pattyn F, Poppe B, Van Roy N, De Paepe A, Speleman F. Accurate normalization of real-time quantitative RT-PCR data by geometric averaging of multiple internal control genes. Genome Biol 2002; 3(7): 1-12.

VanGuilder HD, Vrana KE, Freeman WM. Twentyfive years of quantitative PCR for gene expression analysis. Biotechniques 2008; 44(5): 619-26.

Xie F, Sun G, Stiller JW and Zhang B. Genome-wide functional analysis of the cotton transcriptome by creating an integrated EST database. PLoS One 2011; 6(11): e26980.

Zhong H, Simons JW. Direct comparison of GAPDH, beta-actin, cyclophilin, and 28S rRNA as internal standards for quantifying RNA levels under hypoxia. Biochem Biophys Res Commun 1999; 259 (3): 523-6. 